\title{
Metabolites and Biological Activities of Thymus zygis, Thymus pulegioides, and Thymus fragrantissimus Grown under Organic Cultivation
}

\author{
Andrea F. Afonso ${ }^{1,2,3}$, Olívia R. Pereira ${ }^{3,4}{ }^{(\mathbb{D}}$, Mónica Válega ${ }^{1}$, Artur M. S. Silva ${ }^{1}$ (1) and \\ Susana M. Cardoso 1,* (iD) \\ 1 Department of Chemistry \& QOPNA, University of Aveiro, 3810-193 Aveiro, Portugal; \\ andrea@ipb.pt (A.F.A.); mvalega@ua.pt (M.V.); artur.silva@ua.pt (A.M.S.S.) \\ 2 Public Health Laboratory of Bragança, Local Health Unit, Rua Eng. Adelino Amaro da Costa, \\ 5300-146 Bragança, Portugal \\ 3 Department of Diagnostic and Therapeutic Technologies, Polytechnic Institute of Bragança, \\ School of Health Sciences, Av. D. Afonso V, 5300-121 Bragança, Portugal; oliviapereira@ipb.pt \\ 4 Centro de Investigação de Montanha (CIMO), Instituto Politécnico de Bragança, Campus de Santa Apolónia, \\ 5300-253 Bragança, Portugal \\ * Correspondence: susanacardoso@ua.pt; Tel.: +351-234-370-360; Fax: +351-234-370-084
}

Received: 19 May 2018; Accepted: 18 June 2018; Published: 22 June 2018

\begin{abstract}
Thymus plants are marketed for diverse usages because of their pleasant odor, as well as high nutritional value and wealth of health-promoting phytochemicals. In this study, Thymus zygis, Thymus pulegioides, and Thymus fragrantissimus grown under organic cultivation regime were characterized regarding nutrients and phenolic compounds. In addition, the antioxidant and antibacterial properties of these species were screened. The plants were particularly notable for their high $\mathrm{K} / \mathrm{Na}$ ratio, polyunsaturated fatty acids content and low omega-6/omega-3 fatty acids ratios, which are valuable features of a healthy diet. Caffeic acid and/or its derivatives, mainly rosmarinic acid and caffeoyl rosmarinic acid, represented the majority of the phenolic constituents of these plants, although they were less representative in T. pulegioides, which in turn was the richest in flavones. The latter species also exhibited the highest antioxidant capacity $\left(\mathrm{DPPH}^{*} \mathrm{EC}_{50}\right.$ of $9.50 \pm 1.98 \mu \mathrm{g} / \mathrm{mL}$ and reducing power $\mathrm{EC}_{50}$ of $30.73 \pm 1.48 \mu \mathrm{g} / \mathrm{mL}$ ), while $T$. zygis was the most active towards Gram-positive and Gram-negative bacteria. Overall, the results suggest that the three thyme plants grown in organic farming are endowed with valuable metabolites that give them high commercial value for applications in different industries.
\end{abstract}

Keywords: Thymus; thyme; phenolic compounds; nutrients; antioxidant; antibacterial activity

\section{Introduction}

Thymus plants, belonging to the Lamiaceae family, represent a large botanical genus well known in the West Mediterranean region. Due to their high capacity to adapt to extreme climate conditions concerning temperature and water supply, the plants can often be found in rocks or stones growing in cold and arid conditions [1]. In general, they appear as perennial and subshrubs or shrubs 10 to $30 \mathrm{~cm}$ tall, with small and simple leaves, a quadrangular stem erect to prostate, ramified and prostrated branches, and big clusters of small pink, white, cream or purple flowers [2,3].

Because of its easy growth and the wide variety of Thymus-derived products that can be used by diverse industries, the cultivation of thyme species for commercial purposes has increased greatly in recent decades [4]. Special interest is given to organic farming, since this is recognized as a sustainable agricultural system. Indeed, organic agriculture has developed rapidly worldwide in recent years, 
being presently practiced in approximately 120 countries. At the level of the European Union, the area under organic production increased by about $70 \%$ in the last decade, reaching about 11 million hectares [5]. Moreover, medicinal and aromatic plants represent one of the top 10 crops cultivated under the organic regime. Organically grown medicinal and aromatic products are readily accepted in global markets and command higher prices than those grown with chemical inputs [6]. Indeed, crops grown under an organic regime are considered healthier by consumers, since this agriculture practice restricts the use of synthetic fertilizers, pesticides, and herbicides [7,8]. Moreover, there is evidence that organic agriculture can lead to more valuable products. In this context, the concentrations of a range of polyphenolics such as phenolic acids, flavanones, stilbenes, flavones, flavonols, and anthocyanins were found to be substantially higher in organic crops/crop-based foods in several studies [9]. In particular, Sousa et al. [10] showed that the levels of phenolic compounds in leaves of tronchuda cabbage from organic culture had higher amounts of phenolics, probably due to the interference of mineral fertilizers and pesticides with the biosynthetic pathway of phenolic compounds.

Cultivated Thymus plants can be commercialized for a wide range of applications. In fact, Thymus are amongst the main aromatic plants used as culinary ingredients for fish, meat, salad and vegetable dishes [11,12]. Also, dried thyme leaves are used for teas as well as in other several products such as lotion, bath soap, and toothpaste [1,13]. In addition, thyme-derived products are applied in traditional medicine to treat respiratory and throat ailments, and skin problems such as oily skin, sciatica, acne, dermatitis, parasite affections, eczema, fungal infections, and insect bites, among others [14]. Moreover, thyme essential oil is a globally respected commodity and is currently used in many industries such as food, pharmaceuticals, personal health care, detergents, and insecticides [1,15].

The widespread application of Thymus plants has long been associated with their pleasant taste/odor, but at present, highly valuable products of these plants are closely associated with their high nutritional value and/or predominance of bioactive compounds. Among the latter, essential oils have undoubtedly been the most exploited health promoters of Thymus, being recognized for their antimicrobial, preservative, antispasmodic, diuretic, antihypertensive, and calming properties [12,16,17]. Although less studied, a growing number of investigations have been focused on the potential biological activities of extracts rich in phenolic compounds, and their prospective for application as high-value products [16,17].

The present study aims to evaluate the nutritional composition of three economically important Thymus species (Thymus zygis, Thymus pulegioides, and Thymus fragrantissimus) (Figure S1) cultivated in an organic farming regime, as well as to establish the phenolic profile and biological potencies (antioxidant and antimicrobial) of their respective decoctions. As far as we know, this is the first work focusing on organically grown T. zygis, T. pulegioides, and T. fragrantissimus plants. One must also remark that the chemical composition and/or biological potentials of these botanical species remain poorly studied, even for wild plants. In this regard, Fernandes et al. [18] previously reported the nutritional value of a wild T. pulegioides collected in the northeast of Portugal. In addition, these authors and Kindl et al. [19], also evaluated the antioxidant potential of methanolic or hydroethanolic extracts of wild T. pulegioides (in northeast Portugal and Croatia) against oxidative events.

\section{Results and Discussion}

\subsection{Nutritional Composition}

The nutritional profile of the three Thymus species cultivated under an organic farming regime is shown in Table 1. The dried plants were essentially rich in carbohydrates, varying from 78 to $87 \%$ $\mathrm{dw}$, while protein, fat, and ash contents were in the ranges of 3.6-10.5\%, 2.3-4.5\%, and 5.0-8.2\%, respectively. The levels of these macronutrients in T. pulegioides were 81.2, 8.3, 2.3, and $8.2 \mathrm{~g} / 100 \mathrm{~g}$ dw, respectively, which, compared to those reported by Fernandes et al. [18] for a wild T. pulegioides collected in the northeast of Portugal $(89.4,5.5,0.2$, and $4.9 \mathrm{~g} / 100 \mathrm{~g} \mathrm{dw}$, respectively), presented higher 
non-carbohydrate macronutrients. To our knowledge, there are no previous data on the nutritional value of T. zygis and T. fragrantissimus plants.

T. pulegioides was also the richest species with respect to its mineral content. However, it is worth mentioning that all three plants had high levels of Ca (0.57-1.04 g/100 g dw) and K (1.23-2.19 g/100 g $\mathrm{dw}$ ), but modest $\mathrm{Na}$ amounts, thus representing high $\mathrm{K} / \mathrm{Na}$ suppliers, which is of great importance when aiming to compensate for the modern Western diet, which is typically rich in $\mathrm{NaCl}$. This ratio was particularly high in T. pulegioides, which, due to its richness in K, was established at 294, a fact that can give the plant enormous potential for application in functional foods directed to cardiovascular health claims.

Regarding fatty acids, the results indicated that thyme plants were richer in unsaturated fatty acids (UFA), which represented 69-74\%, whereas saturated fatty acids (SFA) represented 14 to $25 \%$ of the total fatty acids. Among UFA, polyunsaturated fatty acids (PUFA) were the main representatives, ranging from 48 to $49 \%$ in T. zygis and T. pulegioides, to 55\% in T. fragrantissimus. Overall, PUFA comprised linoleic acid (C18: 2n6c) and $\alpha$-linolenic acid (C18: $3 \mathrm{n} 3)$, while monounsaturated fatty acids (MUFA) fraction was composed of oleic acid (C18: 1n9c) and erucic acid (C22: 1n9) (structures in Figure 1).

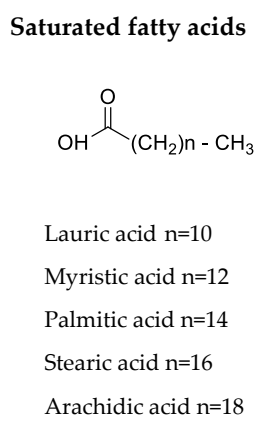

Unsaturated fatty acids

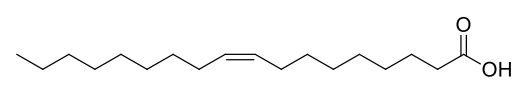

Oleic acid

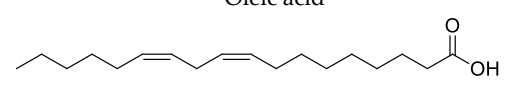

Linoleic acid

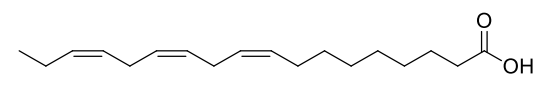

$\alpha$-Linolenic acid

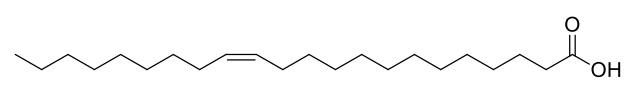

Erucic acid
Flavonols
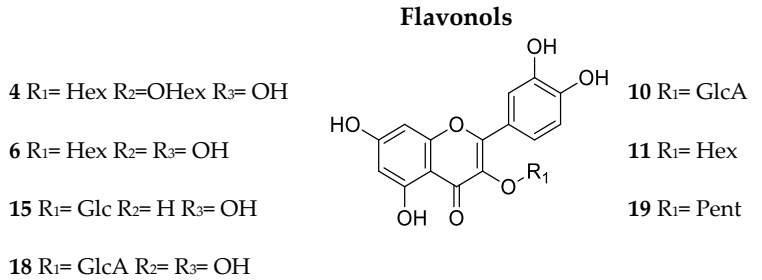

$15 \mathrm{R}_{1}=\mathrm{Glc} \mathrm{R}_{2}=\mathrm{H} \mathrm{R}_{3}=\mathrm{OH}$

$18 \mathrm{R}_{1}=\mathrm{GlcA} \mathrm{R}_{2}=\mathrm{R}_{3}=\mathrm{OH}$

Figure 1. Cont. 
<smiles>O=C(O)C1(O)CC(O)C(O)C(O)C1</smiles>

1<smiles>[R]Oc1cc(C(=O)O)cc(OC)c1OC</smiles>

$2 \mathrm{R}_{1}=\mathrm{Hex}$<smiles>O=C(O)C(O)Cc1ccc(O)c(O)c1</smiles>

3<smiles>O=C(O)/C=C/c1ccc(O)c(O)c1</smiles><smiles>[R]OC(=O)/C=C/c1ccc(O)c(O)c1</smiles><smiles>CC(Cc1ccc(O)c(O)c1)C(=O)O</smiles>

$\mathbf{R}=$<smiles>[R]OC(=O)/C=C/c1ccc(O[R])c(O)c1</smiles><smiles>[X]OC(=O)/C=C/c1ccc(Oc2ccc(/C=C/c3ccc(O)c(O)c3)cc2O)c(/C=C(\C(=O)O)C(=O)O[X])c1</smiles>

Figure 1. Chemical structures of fatty acids and phenolic compounds identified in Thymus zygis, Thymus pulegioides, and Thymus fragrantissimus. Numbers in the figure correspond to the UHPLC-DAD-ESI-MS ${ }^{n}$ peaks of Figure 2.

Although we found several SFA, palmitic acid (C16: 0) was by far the most abundant in the three samples, accounting for $18-24 \%$ of the fatty acids. Because of that, the PUFA/SFA ratio of the thyme plants was considerably high (1.62-1.83). This is particularly relevant when one examines the recommendation of the World Health Organization for the consumption of PUFA-rich foods as part of a healthy lifestyle, aiming at cardiovascular protection [20,21]. Moreover, it must be noted that the omega-6/omega-3 fatty acids ratios fall within the recommended values $(<10)$ [22], and those of the T. fragrantissimus and T. pulegioides species (0.54 and 0.75, respectively) assume relevance due to its low value, which is believed to be associated with the prevention of many chronic diseases, including inflammatory bowel disease, rheumatoid arthritis, asthma, kidney disease, and several other inflammatory conditions [21,23].

Regardless of this generic similarity, specific features could be found among the plants. Linoleic acid was the most abundant fatty acid in T. zygis, while $\alpha$-linolenic acid prevailed in the other species, with percentages of $28 \%$ and $36 \%$ in T. pulegioides and in T. fragrantissimus, respectively. Fernandes et al. [18] have found similar results for T. pulegioides (37\% of $\alpha$-linolenic acid) in a wild T. pulegioides plant. Nevertheless, the present data point to a lower prevalence of SFA and higher amounts of MUFA compared to that study. Naturally, differences may be related to multiple factors, including growth conditions (organic farming versus wild). 
Table 1. Nutritional value of the three Thymus plant species.

\begin{tabular}{|c|c|c|c|}
\hline Total Content & T. zygis & T. pulegioides & T. fragrantissimus \\
\hline Total Carbohydrates (g/100 g dw) & $86.88 \pm 0.51$ & $81.22 \pm 0.90$ & $77.56 \pm 0.16$ \\
\hline Protein $(\mathrm{g} / 100 \mathrm{~g} \mathrm{dw})$ & $3.59 \pm 0.13$ & $8.28 \pm 0.81$ & $10.49 \pm 0.13$ \\
\hline Ash $(\mathrm{g} / 100 \mathrm{~g} \mathrm{dw})$ & $5.02 \pm 0.25$ & $8.24 \pm 0.06$ & $7.66 \pm 0.22$ \\
\hline \multicolumn{4}{|l|}{ Minerals (mg/100 g dw) * } \\
\hline $\mathrm{Na}$ & 7.6 & 7.4 & 9.0 \\
\hline $\mathrm{K}$ & 1229.3 & 2185.6 & 1719.5 \\
\hline $\mathrm{Ca}$ & 566.0 & 1039.4 & 865.6 \\
\hline $\mathrm{Mg}$ & 119.8 & 148.3 & 241.8 \\
\hline $\mathrm{Fe}$ & 4.4 & 1.9 & 7.8 \\
\hline $\mathrm{Mn}$ & 9.8 & 15.7 & 6.9 \\
\hline $\mathrm{Cu}$ & 0.1 & 0.1 & 0.3 \\
\hline $\mathrm{Zn}$ & 2.1 & 1.7 & 2.7 \\
\hline Fat $(\mathrm{g} / 100 \mathrm{~g} \mathrm{dw})$ & $4.52 \pm 0.12$ & $2.27 \pm 0.03$ & $4.30 \pm 0.19$ \\
\hline \multicolumn{4}{|l|}{ Fatty acids (relative \%) * } \\
\hline C12: 0 & 0.48 & 0.5 & 0.7 \\
\hline C14: 0 & 1.2 & 1.1 & 1.4 \\
\hline C16: 0 & 18.8 & 23.6 & 23.3 \\
\hline C18: 0 & 3.2 & 3.3 & 2.8 \\
\hline C18: $1 n 9$ & 16.9 & 19.0 & 8.6 \\
\hline C18: $2 \mathrm{n} 6 \mathrm{c}$ & 32.6 & 20.4 & 19.3 \\
\hline C18: 3n 3 & 15.6 & 27.6 & 36.2 \\
\hline C20: 0 & 2.8 & 1.8 & 2.6 \\
\hline C22: $1 n 9$ & 8.3 & 2.7 & 5.0 \\
\hline SFA & 26.5 & 30.2 & 30.9 \\
\hline MUFA & 25.3 & 20.9 & 13.8 \\
\hline PUFA & 48.3 & 48.9 & 55.3 \\
\hline PUFA/SFA & 1.8 & 1.6 & 1.8 \\
\hline$n-6 / n-3$ & 2.1 & 0.8 & 0.5 \\
\hline Caloric content (kcal/100 g dw) & $402.50 \pm 0.42$ & $378.39 \pm 0.08$ & $390.86 \pm 1.83$ \\
\hline
\end{tabular}

\subsection{Phenolic Characterization of Thymus Decoctions}

The yield range of the decoctions extracts of the three Thymus species was between $12 \%$ and $25 \%$, with minimum and maximum values corresponding to T. zygis and T. pulegioides, respectively (Table 2).

The decoction of T. pulegioides also showed a superior content of total phenolic compounds when compared to the others (391 versus 287-288 $\mu \mathrm{g}$ GAE/ mg extract, $p$-values < 0.01 ) or to decoctions of Thymus herba-barona, Thymus pseudolanuginosus, and Thymus caespititius (236-293 $\mu \mathrm{g} \mathrm{GAE} / \mathrm{mg}$ of extract) [24], or even to aqueous extracts obtained from Thymus serpyllum at 50 and $100{ }^{\circ} \mathrm{C}(79$ and $91 \mu \mathrm{g}$ GAE/mg extract, respectively) [25]. Moreover, the extraction yield of this decoction was close to the one reported by other authors for methanol or $70 \%$ ethanol extracts of T. pulegioides wild plants (24.6 and 22.5, respectively) and its phenolic richness was superior to the latter (391 versus $210 \mu \mathrm{g}$ GAE/mg extract) [18,19].

Table 2. Yield and total phenolic compounds of aqueous extracts of T. zygis, T. pulegioides and T. fragrantissimus.

\begin{tabular}{cccc}
\hline & T. zygis & T. pulegioides & T. fragrantissimus \\
\hline Yield of Extraction (\%) & $12.39 \pm 0.60^{\mathrm{a}}$ & $24.86 \pm 1.71^{\mathrm{b}}$ & $15.67 \pm 4.56^{\mathrm{a}}$ \\
$\begin{array}{c}\text { Total phenolic compounds } \\
(\mu \mathrm{g} \mathrm{GAE} / \mathrm{mg} \text { of extract) }\end{array}$ & $287.86 \pm 18.50^{\mathrm{a}}$ & $390.94 \pm 2.48^{\mathrm{b}}$ & $287.08 \pm 3.76^{\mathrm{a}}$
\end{tabular}

Mean values \pm S.D.; Statistical analysis was performed by one-way ANOVA, followed by Tukey's test. In each line different letters $\left({ }^{\mathrm{a}, \mathrm{b}}\right)$ mean significant differences $(p<0.05)$. 
The phenolic profiles of T. zygis, T. pulegioides and T. fragrantissimus decoctions were evaluated using UHPLC-ESI-DAD-MS ${ }^{2}$ /MS (Figure 2, Table 3). Moreover, the extracted ion chromatogram (EIC) and MS/MS spectrum of the main identified compounds are shown in Figure S2. Consistent with previous studies on Thymus polar extracts [3,24], these were mainly rich in rosmarinic acid (peak 26, UVmax at 290 and $328 \mathrm{~nm}$, and $[\mathrm{M}-\mathrm{H}]^{-}$at $m / z$ 539). Interestingly, its levels (62-82 $\mu \mathrm{g} / \mathrm{mg}$ extract, Table 3) were higher than those previously found for decoctions of T. herba-barona, T. pseudolanuginosus, and T. caespititius (40-56 $\mathrm{\mu g} / \mathrm{mg}$ extract) [24], as well as for hydroethanolic extracts of Thymus $x$ citriodorus (10 $\mathrm{\mu g} / \mathrm{mg}$ extract) [26] and methanolic extracts of Thymus praecox (15 mg/g dry weight) [27]. The same tendency was found for caffeoyl rosmarinic acid isomers (MW 538, eluted in peaks 27, 29, 30, 31 and 32), which amounted from 16 to $63 \mu \mathrm{g} / \mathrm{mg}$ extract in these species, whereas they were only vestigial in T. pseudolanuginosus and T. caespititius or up to $15 \mu \mathrm{g} / \mathrm{mg}$ extract, in T. herba-barona decoctions [24]. Apart from that, levels of caffeoyl rosmarinic acid in hydroethanolic extracts of T. $x$ citriodorus were reported to only reach about $2 \mu \mathrm{g} / \mathrm{mg}$ extract [26]. Notably, caffeic acid and its derivatives (rosmarinic acid, caffeoyl rosmarinic acid, salvianolic acid I/H) represented most of the phenolic components in Thymus aqueous extracts ( $p$-values $<0.01$ ), although they were less representative in T. pulegioides ( $64 \%$ of total phenolic compounds) when compared to the remaining species (close to $80 \%$ ).

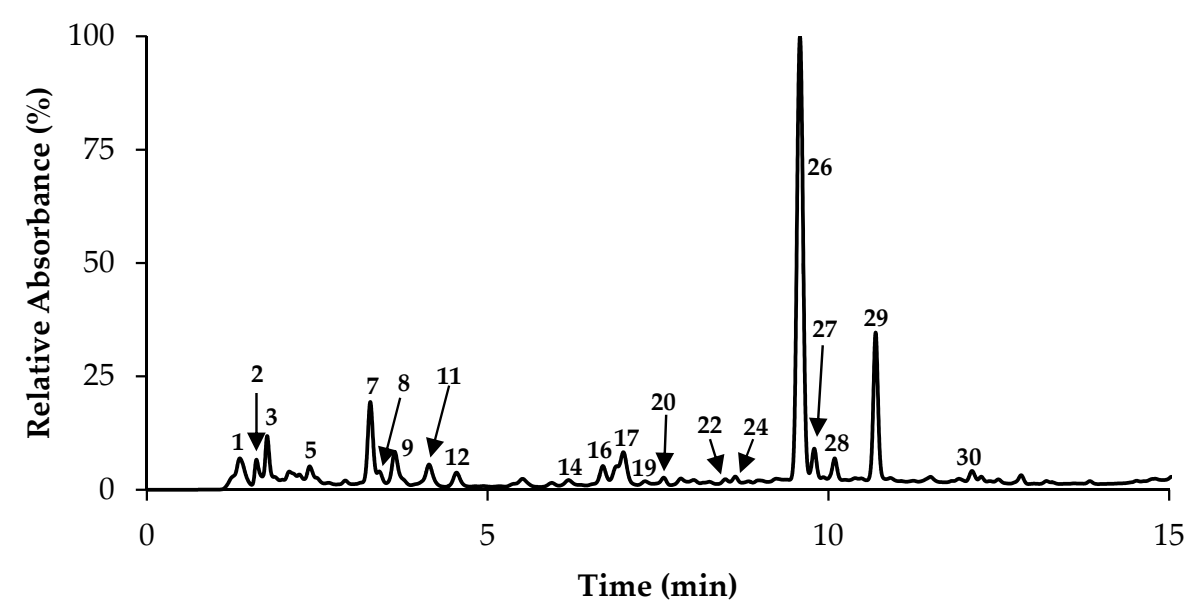

(a)

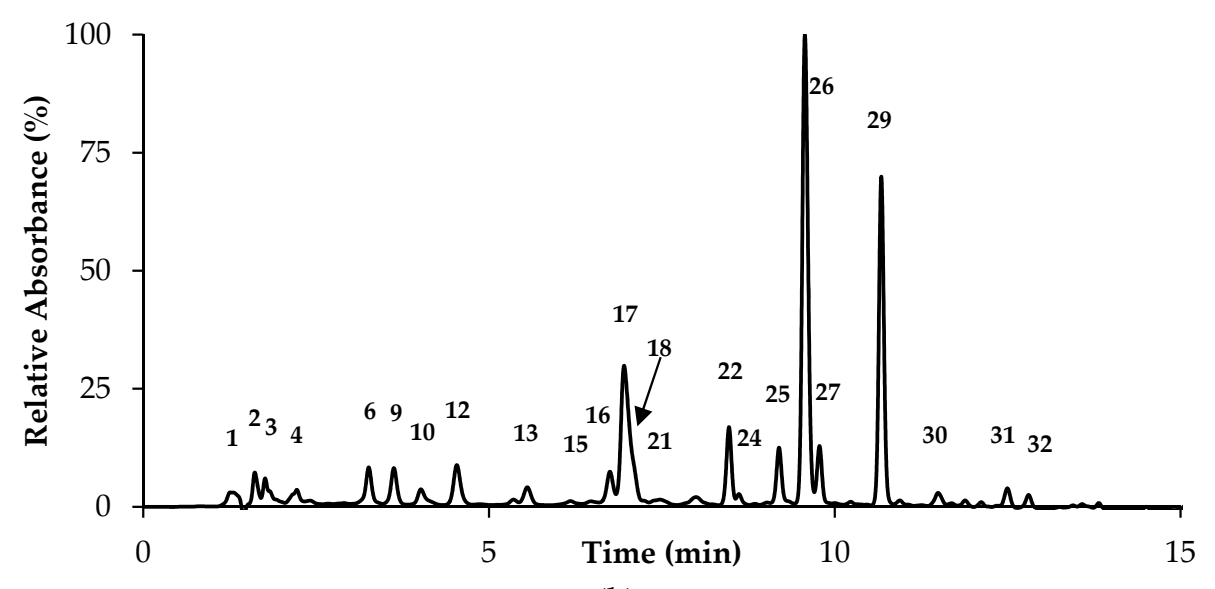

(b)

Figure 2. Cont. 


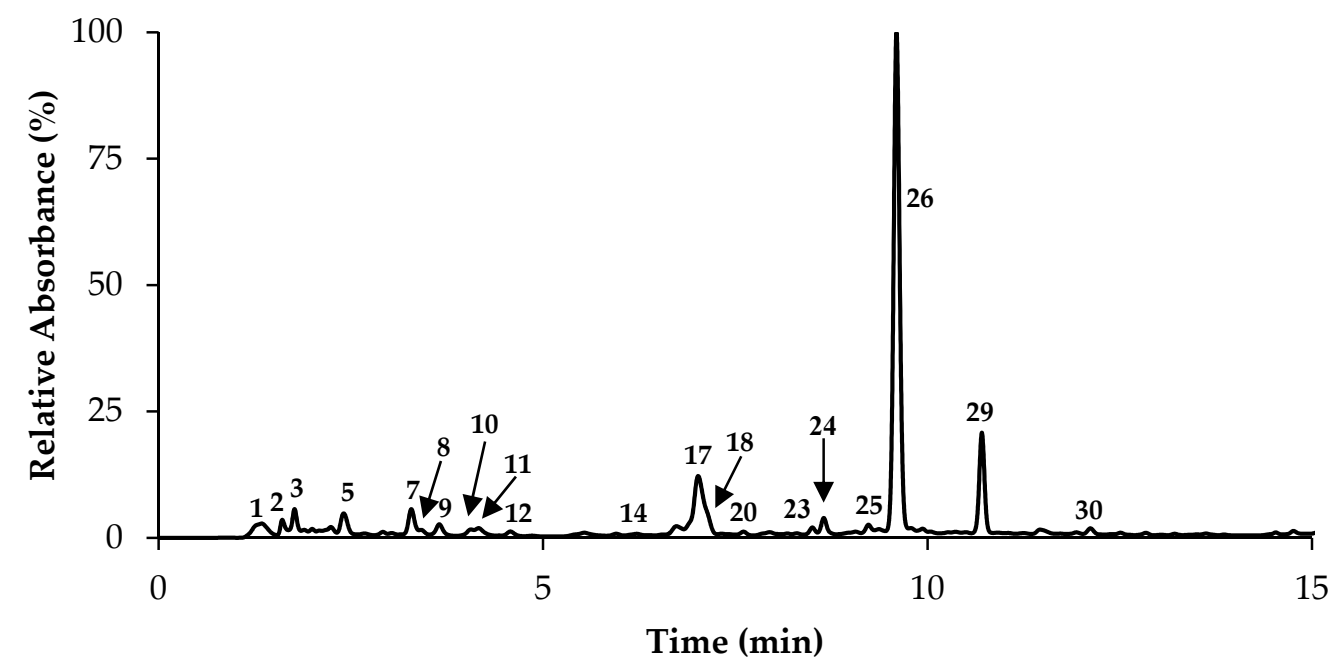

(c)

Figure 2. Chromatographic representation of T. zygis (a), T. pulegioides (b), and T. fragrantissimus (c) aqueous extracts at $280 \mathrm{~nm}$. Numbers in the figure correspond to the UHPLC-DAD-ESI-MS ${ }^{\mathrm{n}}$ peaks described in Table 3.

In turn, the T. pulegioides decoction was the richest in flavones $(55.62 \pm 1.05 \mu \mathrm{g} / \mathrm{mg}$ extract, $p$-values $<0.001$ ), represented mainly by luteolin-O-glucuronide (peaks 17 and $21,[\mathrm{M}-\mathrm{H}]^{-}$at $m / z$ $461 \rightarrow 285$ ), luteolin- $C$-glucoside (peak 12, MW 448), chrysoeriol-O-hexoside (peak 22, $[\mathrm{M}-\mathrm{H}]^{-}$at $\mathrm{m} / \mathrm{z}$ $461 \rightarrow 299,285$ ) and apigenin-O-glucuronide (peak 25, MW 446, UVmax at 267 and 334). Overall, levels of flavones in T. pulegioides decoction were higher than those previously found in T. herba-barona and T. caespititius (22 and $32 \mu \mathrm{g} / \mathrm{mg}$ extract), but lower than T. pseudolanuginosus (73 $\mu \mathrm{g} / \mathrm{mg}$ extract) [24].

The extract of this species was also noticeable due to its greater amounts of flavanones $(23.68 \pm 0.57 \mu \mathrm{g} / \mathrm{mg}$ extract, with statistically significant differences, $p$-values $<0.001)$, mainly comprised by eriodictyol-O-hexoside (factions 6 and 9, UVmax $283 \mathrm{~nm},[\mathrm{M}-\mathrm{H}]^{-}$at $m / z 449 \rightarrow 287$ ), naringenin-O-glucoside (peak 15, UVmax $283 \mathrm{~nm}$, MW 434 and $[\mathrm{M}-\mathrm{H}]^{-}$at $m / z 433 \rightarrow 271$ ), that overall accounted for $19.93 \pm 0.46 \mu \mathrm{g} / \mathrm{mg}$ extract. Please note that the compounds described herein (caffeic acid derivatives and flavonoids, including glycosidic forms) were previously detected in aqueous or methanolic/ethanolic extracts of other Thymus species $[3,26]$. 
Table 3. Identification and quantification of the compounds in the aqueous extracts of T. zygis, T. pulegioides and T. fragrantissimus by UHPLC-DAD-ESI-MS ${ }^{\text {. }}$

\begin{tabular}{|c|c|c|c|c|c|c|c|c|}
\hline NP & $\mathrm{RT}(\min )$ & $\lambda \max$ & Compound & {$[\mathbf{M}-\mathbf{H}]^{-}$} & MS $^{2}$ Main Fragments ESI-MS ${ }^{n}(m / z)$ & T. zig & T. pul & T. fragr \\
\hline 1 & 1.3 & 298 & Quinic Ac & 191 & $111,173,93,85$ & $\mathrm{D}$ & $\mathrm{D}$ & $\mathrm{D}$ \\
\hline 2 & 1.6 & 277 & Syringic Ac hex & 359 & $197,179,135$ & $\mathrm{D}$ & D & $\mathrm{D}$ \\
\hline 3 & 1.8 & 281 & Danshensu & 197 & 179,73 & $\mathrm{D}$ & D & D \\
\hline 4 & 1.9 & 283 & Eriod di-O-hex & 611 & 449,287 & - & $\mathrm{D}$ & - \\
\hline 5 & 2.4 & 271,326 & Api di-C-glc & 593 & $473,503,575,353$ & $1.60 \pm 0.32^{\mathrm{a}}$ & & $2.69 \pm 0.50^{\mathrm{a}}$ \\
\hline 6 & & 283 & Eriod-O-hex (isom1) & 449 & 287 & - & $9.43 \pm 0.21$ & - \\
\hline 7 & 3.3 & 289,321 & CaffAc & 179 & 135 & $8.46 \pm 0.02^{a}$ & & $2.54 \pm 0.14^{b}$ \\
\hline 8 & 3.4 & 285 & SA F der & 375 & 313,179 & $\mathrm{D}$ & - & $\mathrm{D}$ \\
\hline 9 & 3.7 & 283 & Eriod-O-hex (isom2) & 449 & 287 & $6.02 \pm 0.94^{a}$ & $9.90 \pm 0.19^{b}$ & $2.71 \pm 0.03^{c}$ \\
\hline 10 & 4.1 & 281,342 & Querc glcA & 477 & 301 & - & $3.28 \pm 0.03^{a}$ & $1.13 \pm 0.25^{b}$ \\
\hline 11 & 4.2 & 282,342 & Querc-O-hex & 463 & 301 & $2.97 \pm 0.90^{\mathrm{a}}$ & - & $1.48 \pm 0.02^{b}$ \\
\hline 12 & 4.6 & 341 & Lut-C-glc & 447 & $357,285,327$ & $4.86 \pm 0.03^{a}$ & $8.27 \pm 0.13^{b}$ & $2.00 \pm 0.02^{c}$ \\
\hline 13 & 5.6 & 281,342 & $\mathrm{SAI} / \mathrm{H}$ & 537 & 339,493 & - & $\mathrm{D}$ & - \\
\hline 14 & 6.2 & $258,268,342$ & Lut-O-di glc & 593 & 285,447 & $1.19 \pm 0.01^{\mathrm{a}}$ & - & $0.36 \pm 0.02^{b}$ \\
\hline 15 & 6.2 & 283 & Nar-O-glc & 433 & 271,313 & - & $1.90 \pm 0.97$ & $0.00+0$ \\
\hline 16 & 6.8 & 282,333 & Scut-O-glcA & 461 & $285,175,284,257$ & D & D & - \\
\hline 17 & 7.0 & $254,265,345$ & Lut-O-glcA (isom1) & 461 & 285 & $7.57 \pm 0.05^{\mathrm{a}}$ & $26.14 \pm 0.78^{b}$ & $16.86 \pm 0.21^{c}$ \\
\hline 18 & 7.1 & 283 & Eriod-O-glcA & 463 & $287,175,151$ & - & D & $\mathrm{D}$ \\
\hline 19 & 7.3 & 282,336 & Querc-O-pent & 433 & 301 & $\mathrm{D}$ & - & - \\
\hline 20 & & 288,321 & RA hex & 521 & 359 & $\mathrm{D}$ & - & D \\
\hline 21 & 7.6 & $254,267,344$ & Lut-O-glcA (isom2) & 461 & 285 & - & D & - \\
\hline 22 & & 240,339 & Chrys-O-hex & 461 & 299,285 & $0.78 \pm 0.01^{a}$ & $12.00 \pm 0.15^{b}$ & \\
\hline 23 & 8.5 & 281 & CaffAc der & 553 & $465,311,535,357$ & - & - & D \\
\hline 24 & 8.7 & 283 & Sagerinic Ac & 719 & $359,539,521,341$ & D & D & $\mathrm{D}$ \\
\hline 25 & 9.3 & 267,334 & Api-O-glcA & 445 & 269,175 & $\mathrm{D}$ & $9.20 \pm 0.21^{\mathrm{a}}$ & $1.76 \pm 0.10^{\mathrm{b}}$ \\
\hline 26 & 9.6 & 290,328 & RA & 359 & $223,197,179$ & $62.36 \pm 2.72^{\mathrm{a}}$ & $81.65 \pm 7.02^{b}$ & $81.04 \pm 7.93^{b}$ \\
\hline 27 & 9.8 & 287,311 & CaffRA (isom1) & 537 & $493,515,357,335,519,153$ & $2.79 \pm 0.24^{\mathrm{a}}$ & $5.25 \pm 0.19^{\mathrm{b}}$ & - \\
\hline 28 & 10.1 & 287,328 & SAB & 717 & $519,357,555,359$ & $1.89 \pm 0.20$ & - & - \\
\hline 29 & 10.7 & 290,323 & CaffRA (isom2) & 537 & $493,359,519,179$ & $19.40 \pm 0.76^{\text {a }}$ & $57.73 \pm 1.95^{b}$ & $16.21 \pm 0.54^{c}$ \\
\hline 30 & 12.1 & 288,322 & CaffRA (isom3) & 537 & $375,493,357,359$ & $\mathrm{D}$ & $\mathrm{D}$ & $\mathrm{D}$ \\
\hline 31 & 12.5 & 287,328 & CaffRA (isom4) & 537 & $439,519,357,197,493,323,331,313$ & - & $\mathrm{D}$ & - \\
\hline \multirow{6}{*}{32} & 12.8 & 288,323 & CaffRA (isom5) & 537 & $519,359,357,339,235,493,279,207$ & - & $\mathrm{D}$ & - \\
\hline & & & & & Total & $119.90 \pm 3.31^{\mathrm{a}}$ & $225.79 \pm 15.08^{b}$ & $126.65 \pm 9.73^{\mathrm{a}}$ \\
\hline & & & & & Caffeic acid and derivatives & $94.89 \pm 1.84^{\mathrm{a}}$ & $144.63 \pm 8.79 \mathrm{~b}$ & $101.12 \pm 6.75^{\mathrm{a}}$ \\
\hline & & & & & Flavones & $16.01 \pm 0.27$ a & $55.62 \pm 1.05^{b}$ & $21.67 \pm 0.59^{c}$ \\
\hline & & & & & Flavonols & $2.97 \pm 0.90^{\mathrm{a}}$ & $3.28 \pm 0.03^{\mathrm{a}}$ & $2.62 \pm 0.25^{\mathrm{a}}$ \\
\hline & & & & & Flavanones & $6.02 \pm 0.94^{a}$ & $19.93 \pm 0.46^{\mathrm{b}}$ & $2.71 \pm 0.03^{c}$ \\
\hline
\end{tabular}

NF-Number of peak represented in Figure 2; D-Detected; T. zig-T. zygis; T. pul-T. pulegioides; T. fragr-T. fragrantissimus; Ac-acid; Api-Apigenin; CaffAc-Caffeic acid; Caff-Caffeoyl; Chrys-Chrysoeriol; Der-Derivative; Eriod-Eriodictyol; Glc-Glucoside; GlcA-Glucuronide; Hex-Hexoside; Lut-Luteolin; Nar-Naringenin; Pent-Pentoside; Querc-Quercetin; RA-Rosmarinic acid; SA-Salvianolic acid; Scut-Scutellarein; Values are expressed as $\mu \mathrm{g} / \mathrm{mg}$ extract; In each line different letters $(\mathrm{a}, \mathrm{b}, \mathrm{c})$ mean significant differences $(p<0.05)$. 


\subsection{Antioxidant Activity}

It is widely known that the antioxidant capacity of plant extracts are closely associated with phenolic components, which might interact with free radicals through electron or hydrogen donation [28]. In this study, the antioxidant potency of Thymus decoctions was screened by two generalized assays, namely the $\mathrm{DPPH}^{\bullet}$ scavenging method and reducing power, which respectively evaluate the ability to trap the synthetic free radicals $\mathrm{DPPH}^{\bullet}$ and to reduce ferric ion $\left(\mathrm{Fe}^{3+}\right)$ to ferrous ion $\left(\mathrm{Fe}^{2+}\right)$. In general, the extracts presented a high antioxidant capacity, since $\mathrm{EC}_{50}$ values were up to twice as high as the commercial reference compounds (Table 4). Among the three extracts, T. pulegioides had the lowest $\mathrm{DPPH}^{\bullet} \mathrm{EC}_{50}$ value $(9.50 \pm 1.98 \mu \mathrm{g} / \mathrm{mL})$, which corresponded to about 1.4-fold of ascorbic acid $\left(\mathrm{EC}_{50}=6.9 \pm 0.5\right)$, while $T$. fragantissimus and $\mathrm{T}$. zygis were established at $13 \mu \mathrm{g} / \mathrm{mL}$. This fact shows the greater ability of T. pulegioides to scavenge the free radical $\mathrm{DPPH}^{\bullet}$ in comparison to the other two plant species and can possibly be associated with its higher phenolic contents. Interestingly, regardless of the higher ferric ion reduction tendency $\left(\mathrm{EC}_{50}=30.73 \pm 1.48 \mu \mathrm{g} / \mathrm{mL}\right)$, the superiority of this extract was not so clear, suggesting that non-phenolic components might also play a relevant role in this reaction.

Table 4. Antioxidant and antibacterial properties of aqueous extracts from T. zygis, T. pulegioides and T. fragrantissimus.

\begin{tabular}{|c|c|c|c|c|}
\hline & T. zygis & T. pulegioides & T. fragrantissimus & Standard \\
\hline \multicolumn{5}{|l|}{ Antioxidant properties } \\
\hline $\mathrm{DPPH}^{\bullet}(1)(\mu \mathrm{g} / \mathrm{mL})$ & $12.65 \pm 2.30^{\mathrm{a}, \mathrm{b}}$ & $9.50 \pm 1.98^{a, b}$ & $12.87 \pm 3.79^{\mathrm{a}}$ & $6.90 \pm 0.5^{b}$ \\
\hline Reducing Power $(2)(\mu \mathrm{g} / \mathrm{mL})$ & $33.66 \pm 1.93^{\mathrm{a}}$ & $30.73 \pm 1.48^{\mathrm{a}}$ & $32.44 \pm 4.27^{\mathrm{a}}$ & $16.30 \pm 1.5^{\mathrm{b}}$ \\
\hline \multicolumn{5}{|c|}{ Antibacterial properties ${ }^{(3)}(\mathrm{MIC} / \mathrm{MBC}, \mathrm{mg} / \mathrm{mL})$} \\
\hline \multicolumn{5}{|l|}{ G (+) bacteria } \\
\hline Staphylococcus aureus & $1.13 / 1.13$ & $5.75 / 5.75$ & $3.75 / 3.75$ & $0.25 / 0.25$ \\
\hline Staphylococcus epidermidis & $4.50 / 4.50$ & $5.75 / 11.50$ & $7.50 />7.50$ & $<0.06 /<0.06$ \\
\hline \multicolumn{5}{|l|}{ G (-) bacteria } \\
\hline Salmonella typhimurium & $4.50 / 4.50$ & $5.75 / 11.50$ & $7.50 / 7.50$ & $0.50 / 0.50$ \\
\hline Escherichia coli & $>4.5 />4.5$ & $>11.50 />11.50$ & $7.50 />7.50$ & $0.50 / 0.50$ \\
\hline Pseudomonas aeruginosa & $4.5 />4.5$ & $5.75 / 11.50$ & $7.50 />7.50$ & $0.50 / 1.0$ \\
\hline
\end{tabular}

(1) Amount of extract required to reduce $50 \%$ of the $60 \mu \mathrm{M}$ radical 2,2-diphenyl-1-picrylhydrazyl (DPPH ${ }^{\bullet}$ ); Ascorbic acid was used as reference compound; (2) Amount of extract able to provide 0.5 of absorbance by reducing $3.5 \mu \mathrm{M}$ $\mathrm{Fe}^{3+}$ to $\mathrm{Fe}^{2+} ; 2,6$-Di-tert-butyl-4-methylphenol was used as reference compound; Mean values \pm S.D.; Statistical analysis was performed by one-way ANOVA, followed by Tukey's test. In each line different letters (a,b) mean significant differences $(p<0.05) ;{ }^{(3)}$ Nisin was used as reference compound. Mean values; MIC: minimum inhibitory concentration; MBC: minimum bactericidal concentration.

The high antioxidant ability herein described for T. pulegioides decoctions exceeded that previously described for the methanolic extract from a wild T. pulegioides plant $\left(\mathrm{EC}_{50}=680 \pm 30\right.$ and $490 \pm 30 \mu \mathrm{g} / \mathrm{mL}$ $\mathrm{DPPH}^{\bullet}$ and reducing power assays, respectively) [18]. More recently, Kindl et al. [19] found promising results for an hydroethanolic extract of wild Croatian T. pulegioides plants, reporting $\mathrm{DPPH}^{\bullet} \mathrm{EC}_{50}=$ $4.18 \pm 0.02 \mu \mathrm{g} / \mathrm{mL}$ and reducing power $\mathrm{EC}_{50}=11.39 \pm 0.07 \mu \mathrm{g} / \mathrm{mL}$, which corresponded to about 1.7-2.5 times those of the reference commercial compounds [19]. To our knowledge, there are no literature data regarding the antioxidant abilities of aqueous extracts from T. zygis, T. pulegioides or T. fragantissimus origin. Still, the high abilities reported herein for decoctions are in line with those previously described by us for T. herba-barona, T. pseudolanuginosus, and T. caespititius aqueous extracts [24]. However, Baharfar et al. [29] also observed that a Thymus kotschyanus aqueous extract could request $\mathrm{DPPH}^{\bullet}$ with half the potency of ascorbic acid.

\subsection{Antibacterial Activity}

In opposition to Thymus essential oils, the antibacterial effects of polar extracts from Thymus plants have been scarcely exploited. In the present study, we evaluated the inhibitory activities of T. zygis, 
T. pulegioides or T. fragantissimus aqueous extracts against the Gram-positive bacteria Staphylococcus aureus and Staphylococcus epidermidis, and the Gram-negative bacteria Salmonella typhimurium, Escherichia coli, and Pseudomonas aeruginosa, through the broth microdilution assay.

Interestingly, T. zygis decoctions were the most active among the three plant samples. As the levels of phenolic compounds in this decoction were below those of T. pulegioides, the results suggest that phenolic components do not lead this bioactivity. Staphylococcus aureus was the most sensitive species to thyme decoctions, with its growth and viability being inhibited at $1.13,3.75$, and $5.75 \mathrm{mg} / \mathrm{mL}$ for T. zygis, T. fragantissimus, and T. pulegioides, respectively (Table 4). The results, combined with those previously reported for T. herba-barona, T. pseudolanuginosus, and T. caespititius allow us to conclude that, among the six aqueous extracts of thyme [24], T. herba-barona and T. zygis (MIC/MBC of $0.6 \mathrm{mg} / \mathrm{mL}$ and of 1.13, respectively) are the two most active towards Staphylococcus aureus. Overall, MIC and MBC for the six thyme species against this bacterium were established in the range of 0.6 to $5.75 \mathrm{mg} / \mathrm{mL}$, which is in accordance with the reported data for thyme extracts of distinct origins. In this context, Benbelaïd et al. [30] reported an MIC value of $1.0 \mathrm{mg} / \mathrm{mL}$ for an aqueous extract of Thymus lanceolatus, while MIC values of $6.25 \mathrm{mg} / \mathrm{mL}, 5.0 \mathrm{mg} / \mathrm{mL}$, and $0.5 \mathrm{mg} / \mathrm{mL}$ were previously reported for ethanolic extracts of Thymus vulgaris, and methanolic and ethanolic extracts of Thymus capitatus [31-33].

Among the tested Gram-negative bacteria, S. typhimurium was the most susceptible to Thymus extracts. Both the growth and viability of $S$. typhimurium were inhibited at $4.5 \mathrm{mg} / \mathrm{mL}$ by T. zygis and at $7.5 \mathrm{mg} / \mathrm{mL}$ by T. fragrantissimus. Instead, T. pulegioides inhibited bacterial growth at $5.75 \mathrm{mg} / \mathrm{mL}$, but its viability was only affected at higher levels (MBC $11.5 \mathrm{mg} / \mathrm{mL}$ ). Combined with our previous results for T. herba-barona, T. pseudolanuginosus, and T. caespetitius decoctions (MIC in the range of 3.5-7 mg/mL) [24], it may be suggested that, to inhibit S. typhimurium, aqueous extracts of thyme should be used in high concentrations. These results are also consistent with those from other authors. In particular, Benbelaiid et al. [30] reported a MIC value of $4.0 \mathrm{mg} / \mathrm{mL}$ when S. typhimurium was treated with a water extract from T. lanceolatus. Values of the same magnitude were reported for a methanolic extract of T. capitatus (MIC $=6 \mathrm{mg} / \mathrm{mL}$ ) [32], or hydroethanolic extracts from T. vulgaris and Thymus caramanicus (MIC values of 12.5 and $2.6 \mathrm{mg} / \mathrm{mL}$, respectively) [31].

In turn, P. aeruginosa and E. coli were even more resistant to thyme extracts, albeit at different levels. While P. aeruginosa growth was inhibited by all samples (MIC values of $4.5,5.75$, and $7.5 \mathrm{mg} / \mathrm{mL}$ for T. zygis, T. pulegioides, and T. fragantissimus, respectively), only the latter species negatively impacted E. coli growth at $7.5 \mathrm{mg} / \mathrm{mL}$. Moreover, T. pulegioides was able to kill P. aeruginosa $(\mathrm{MBC}=11.5 \mathrm{mg} / \mathrm{mL})$, while no effect on the viability of E. coli was observed. Thymus ethanolic extracts have been previously demonstrated to inhibit P. aeruginosa, with MIC values of $2.0 \mathrm{mg} / \mathrm{mL}$ (T. capitatus) [33] and $0.25 \mathrm{mg} / \mathrm{mL}$ (T. lanceolatus) [30], but no data on their ability to kill this bacterium were delivered. Likewise, ethanolic extracts of T. capitatus, T. vulgaris, T. caramanicus, and T. lanceolatus were shown to inhibit the growth of E. coli strains (MIC in the range of $0.5-8 \mathrm{mg} / \mathrm{mL}$ ) $[31,33]$ although no information was given about their effects on the viability of this bacterium.

\section{Materials and Methods}

\subsection{Chemicals}

Rosmarinic acid, apigenin-7-O-glucoside, luteolin-7-O-glucoside and eriodictyol-7-O-glucoside were obtained from Extrasynthese (Genay, France). Gallic acid, nisin, ascorbic acid and 2,6-Di-tert-butyl-4-methylphenol and the fatty acids methyl ester (FAME) reference standard mixture 37 (fatty acids C4 to C24; standard 47885-U) from Supelco (Bellefonte, PA, USA) were obtained from Sigma Chemical Co (St. Louis, MO, USA). Folin-Ciocalteu reagent, $\mathrm{Na}_{2} \mathrm{CO}_{3}$, formic acid and ethanol were purchased from Panreac (Barcelona, Spain). n-hexane, methanol, and acetonitrile with HPLC purity were purchased from Lab-Scan (Lisbon, Portugal). Mueller-Hinton agar was obtained from VWR, Prolabo Chemicals (Radnor, PA, USA). Water was treated in a Direct-Q ${ }^{\circledR}$ water purification system (Merck Life Science, Darmstadt, Germany). 


\subsection{Plant Cultivation and Material}

The T. zygis, T. fragantissimus, and T. pulegioides species have been cultivated under an organic regime by Ervital (Mezio-Castro Daire, Portugal, GPS coordinates 40.976351, -7.903492). The cultivation soil was of granitic origin, medium to coarse in texture. It was moderately acidic ( $\mathrm{pH}$ in water 5.6), with an organic matter content of 3.9\%, with low levels of extractable phosphorus (18 ppm) and high levels of extractable potassium (110 ppm). During the time of cultivation (April 2014-June 2015), local temperatures ranged from $2{ }^{\circ} \mathrm{C}$ to $27^{\circ} \mathrm{C}$. Minimum values were registered in winter (November 2014 to February $2015,2{ }^{\circ} \mathrm{C}-12{ }^{\circ} \mathrm{C}$ ), while temperatures in the spring varied between $11{ }^{\circ} \mathrm{C}$ to $22^{\circ} \mathrm{C}$ and reached a maximum of $27^{\circ} \mathrm{C}$ in June 2015 . Relative humidity varied from $2 \%$ to $90 \%$ with $29 \%$ on average, while the average total precipitation was $75 \mathrm{~mm}(65-94 \mathrm{~mm})$.

No chemical or bacteriological treatment was applied to the plants. Their appearance and behavior were regularly monitored to ensure their health and the absence of pathogens. Whenever appropriate, weeds were removed from the surrounding soil.

The aerial parts of each individual Thymus (flowers, leaves, and stems) were collected and dried in a ventilated incubator at 20 to $35^{\circ} \mathrm{C}$ for three to five days. After drying, the plants were transported in Kraft paper-type bags to the lab, where they were kept frozen until use.

\subsection{Extraction of Phenolic Compounds}

The extraction of phenolic compounds was performed according to the method described by Ferreira et al. [34], with adaptations. Briefly, $0.5 \mathrm{~mm}$ mesh powder of the aerial parts (flowers, leaves, and stems) of T. zygis, T. fragantissimus, and T. pulegioides ( $5 \mathrm{~g}$ ) were extracted for $15 \mathrm{~min}$ using a decoction 20:1 (5 g in $100 \mathrm{~mL}$ of water), filtrated, and concentrated using a rotary evaporator. The concentrate was defatted with $n$-hexane $(1: 1 v / v)$ and freeze-dried. This procedure was performed in three independent assays.

\subsection{Nutritional Value}

The chemical composition of samples was determined according to AOAC methods [35]. Crude protein content $(\mathrm{N} \times 6.25)$ of the samples was estimated through the macro-Kjeldahl method. Ash content was determined by incineration in a muffle furnace at $550{ }^{\circ} \mathrm{C}$ for $6 \mathrm{~h}$ and gravimetric quantification. Crude fat was obtained by Soxhlet extraction with light petroleum for $8 \mathrm{~h}$, followed by filtration through a $0.2 \mu \mathrm{m}$ nylon filter, solvent removal in a rotary evaporator, and drying, followed by gravimetric quantification. Total carbohydrates were calculated by difference. Calorific content was calculated according to the following equation: Energy $(\mathrm{kcal})=4 \times(\mathrm{g}$ protein $+\mathrm{g}$ carbohydrates $)+9 \times(\mathrm{g}$ fat $)[18]$.

For mineral determination, approximately $1 \mathrm{~g}$ of ash was digested with nitric acid. After digestion, samples were filtered and the volume adjusted to $100 \mathrm{~mL}$ with ultrapure water. Minerals (Na, K, Ca, $\mathrm{Mg}, \mathrm{Fe}, \mathrm{Mn}, \mathrm{Cu}$, and $\mathrm{Zn}$ ) were quantified in a Perkin Elmer Analyst 100 flame atomic absorption spectrometer (Villepinte, France) equipped with a single hollow cathode lamps for each element and an air-acetylene burner [36].

Fatty acids were analyzed by transesterification of the fat fraction in the presence of sodium methoxide. The crude fat $(1 \mathrm{~g})$ was placed in a 15-mL glass tube and rod crushed and dissolved in $6 \mathrm{~mL}$ of $n$-heptane. Next, $400 \mu \mathrm{L}$ of $0.2 \mathrm{M}$ sodium methoxide were added to each sample and the tube was vigorously stirred in a vortex for 1-2 min at room temperature, allowing the formation of fatty acid methyl esters (FAME) from triglycerides. After decanting, sample supernatants were filtered through a $0.2 \mu \mathrm{m}$ nylon filter from Milipore and injected in the gas chromatography system. Fatty acids were analyzed in a DANI 1000 gas chromatographer (GC) equipped with a split/splitless injector and a flame ionization detector (FID), following the method used by Fernandes et al. [18]. The identification was performed by comparing the relative retention times from samples with FAME peaks (standard mixtures). The results were recorded and expressed as a relative percentage of each fatty acid. 


\subsection{Identification and Quantification of Phenolic Compounds}

The total phenolic content of each Thymus extract was determined according to the adapted Folin-Ciocalteu colorimetric method, as described by Pereira et al. [37]. The individual phenolic compounds were identified through UHPLC-DAD-ESI-MS ${ }^{\mathrm{n}}$ analysis of extracts $(5 \mathrm{mg} / \mathrm{mL})$, as described by Afonso et al. [24]. Elution was carried out with a mixture of $0.1 \%(v / v)$ of formic acid in water (solvent A) and acetonitrile (solvent B) and the flow rate used was $0.2 \mathrm{~mL} / \mathrm{min}^{-1}$, following the same program. UV-Vis spectral data for all peaks accumulated in the range $200-600 \mathrm{~nm}$ and the chromatographic profiles were recorded at 280,320, and $340 \mathrm{~nm}$. The mass spectrometer used was a Thermo LTQ XL (Thermo Scientific, San Jose, CA, USA) ion trap MS, equipped with an ESI source with Thermo Xcalibur Qual Browser software. The instrument was operated in negative-ion mode and the full scan covered the mass range from $\mathrm{m} / z 100$ to 2000 . Nitrogen above $99 \%$ purity was used and the gas pressure was $520 \mathrm{kPa}$ (75 psi). ESI needle voltage set at $5.00 \mathrm{kV}$ and an ESI capillary temperature of $275{ }^{\circ} \mathrm{C}$. CID-MS/MS and MS ${ }^{n}$ experiments were simultaneously acquired for precursor ions using helium as the collision gas with collision energy of 25-35 arbitrary units.

For quantitative experiments, the limits of detection (LOD) and quantification (LOQ) were calculated from the parameters of the calibration curves obtained by injection of known concentrations of the exact or structurally related standard compounds represented in Table S1.

\subsection{Antioxidant Activity}

\subsection{1. $\mathrm{DPPH}^{\bullet}$ Scavenging Test}

The scavenging capacity of different concentrations $(0.05-0.8 \mathrm{mg} / \mathrm{mL})$ of T. zygis, T. fragantissimus, and T. pulegioides extracts was tested using a DPPH radical test, as described before [38]. Ascorbic acid was used as the positive control.

\subsubsection{Reducing Power Test}

The ability of T. zygis, T. fragantissimus, and T. pulegioides $(0.05-0.25 \mathrm{mg} / \mathrm{mL})$ aqueous extracts to reduce iron (III) was assessed by the method previously described [39]. 2,6-Di-tert-butyl-4-methylphenol was used as the positive control.

\subsection{Antimicrobial Activity}

The antibacterial potential of the Thymus polar extracts was evaluated against five bacterial strains, including Gram-positive bacteria (S. epidermidis NCTC 11047 and S. aureus NCTC 6571) and Gram-negative bacteria (S. typhimurium NCTC 12023, E. coli NCTC 9001, and P. aeruginosa NCTC 10662) from the National Collection of Type Cultures, operated by Public Health England. All strains were cultured in Mueller-Hinton agar and incubated at $37^{\circ} \mathrm{C}$ for $24 \mathrm{~h}$.

The MIC and MBC of aqueous solutions of T. zygis, T. fragantissimus, and T. pulegioides were determined by the broth microdilution method, using an adapted method previously described by Afonso et al. [24]. Nisin, an antibacterial polypeptide approved as a food preservative, was used as the positive control [40].

\subsection{Statistical Analysis}

One-way analysis of variance (ANOVA) followed by Tukey's test were used to detect any significant differences among different means. Alternatively, Student's $t$ test was used to determine the significant difference between two different samples. A $p$-value under 0.05 was assumed to indicate a significant difference. The results were analyzed using GraphPad Prism 6 (GraphPad Software, San Diego, CA, USA). 


\section{Conclusions}

The nutritional composition, phenolic profile, antioxidant and antimicrobial activities of three species of Thymus grown under organic farming are reported within this study. Based on our results, it is possible to infer that these thyme species present a richness of polyunsaturated fatty acids and an interesting omega-6/omega-3 fatty acids ratio, along with high $\mathrm{K} / \mathrm{Na}$ ratios that can contribute to cardiovascular protection. T. pulegioides presented the highest antioxidant capacity, consistent with its high content of polyphenols, which were mainly composed of rosmarinic acid and caffeoyl rosmarinic acid, also showing considerable levels of flavones (luteolin- $\mathrm{C}$-glucoside, luteolin-O-glucuronide, and apigenin-O-glucuronide) and flavanones (eriodictyol-O-hexoside isomers). In addition, aqueous extracts obtained from these Thymus species, particularly T. zygis, showed antibacterial potential.

Supplementary Materials: Supplementary materials can be found in a separate file: Figure S1: Pictures of Thymus zygis (a), Thymus pulegioides (b) and Thymus fragrantissimus (c); Figure S2: Extracted ion chromatograms and (inset) mass spectrum of ESI-MS ${ }^{2}$ of the corresponded ion of main phenolic compounds identified in Thymus zygis, Thymus pulegioides and Thymus fragrantissimus by UHPLC-DAD-ESI-MS ${ }^{n}$; Table S1: Linearity, LOD and LOQ of the standard compounds used as references.

Author Contributions: A.F.A. and O.R.P. performed the majority of the experimental work, the analysis, and interpretation of data, and wrote the paper; M.V. contributed with mineral analysis; A.M.S.S. co-wrote the manuscript; S.M.C. coordinated the work and co-wrote the paper.

Acknowledgments: The authors wish to acknowledge the Foundation for Science and Technology (FCT), the European Union, the National Strategic Reference Framework (QREN), the European Regional Development Fund (FEDER), and Operational Programme Competitiveness Factors (COMPETE), for funding the Organic Chemistry Research Unit (QOPNA) (FCT UID/QUI/00062/2013) and Mountain Research Center (CIMO) (UID/AGR/00690/2013), through national funds and where applicable co-financed by FEDER, within the PT2020 Partnership Agreement. Susana Cardoso wishes to thank the research contract under the project AgroForWealth: Biorefining of agricultural and forest by-products and wastes: integrated strategic for valorisation of resources towards society wealth and sustainability (CENTRO-01-0145-FEDER-000001), funded by Centro2020, through FEDER and PT2020.

Conflicts of Interest: The authors declare no conflict of interest.

\section{References}

1. Pirbalouti, A.; Bistghani, Z.; Malekpoor, F. An overview on genus Thymus. J. Herb. Drugs 2015, 6, 93-100.

2. Morales, R. The history, botany and taxonomy of the genus Thymus. In Thyme, the Genus Thymus; Stahl-Biskup, E., Sáez, F., Eds.; Taylor \& Francis: London, UK, 2002; ISBN 0415284880.

3. Pereira, O.R.; Cardoso, S.M. Overview on Mentha and Thymus Polyphenols. Curr. Anal. Chem. 2013, 9, 382-396. [CrossRef]

4. Rougemont, G.M. A Field Guide to the Crops of Britain and Europe; Collins: London, UK, 1989; ISBN 9780002197137.

5. Willer, H.; Schaack, D.; Lernoud, J. Organic Farming and Market Development in Europe and the European Union. In The World of Organic Agriculture-Statistics and Emerging Trends 2017; Organics International: Bonn, Germany, 2017.

6. Rajeswara Rao, B.; Rajput, D. Organic Farming: Medicinal and Aromatic Plants. In National Seminar on Organic Farming: Current Scenario and Future Thrust; A.N.G.R. Agricultural University: Hyderabad, India, 2005.

7. Brezeanu, C.; Brezeanu, P.M.; Ambaras, S.; Robu, T.; Dobrescu, A. Prioritization of the écologie cultivation of certain species which are less spread, but have multiple potential uses (culinary, medicinal, melliferous, decorative). Acta Hortic. 2016, 1125, 91-97. [CrossRef]

8. Malik, A.A.; Ahmad, J.; Abdin, M.Z. Development of organic cultivation of medicinal plants in the North India. Herba Pol. 2013, 59. [CrossRef]

9. Barański, M.; Średnicka-Tober, D.; Volakakis, N.; Seal, C.; Sanderson, R.; Stewart, G.B.; Benbrook, C.; Biavati, B.; Markellou, E.; Giotis, C.; et al. Higher antioxidant and lower cadmium concentrations and lower incidence of pesticide residues in organically grown crops: A systematic literature review and meta-analyses. Br. J. Nutr. 2014, 112, 794-811. [CrossRef] [PubMed]

10. Sousa, C.; Valentão, P.; Pereira, D.M.; Andrade, P.B. Phytochemical and antioxidant characterization of Brassica oleracea var. costata extracts. Recent Prog. Med. Plants 2009, 24, 299-328. 
11. Horváth, G.; Szabó, L.; Héthelyi, É.; Lemberkovics, É. Essential oil composition of three cultivated Thymus chemotypes from Hungary. J. Essent. Oil Res. 2006, 18, 315-317. [CrossRef]

12. Zarzuelo, A.; Crespo, E. The medicinal and non-medicinal uses of thyme. In Thyme, the Genus Thymus; Stahl-Biskup, E., Sáez, F., Eds.; Taylor \& Francis: London, UK, 2002; ISBN 0415284880.

13. Kiani, M.; Firoozian, F.; Moradkhani, S. Formulation and physicochemical evaluation of toothpaste formulated with Thymus vulgaris essential oil. J. HerbMed Pharmacol. 2017, 6, 130-135.

14. Stahl-Biskup, E. Thyme as a herbal drug_-Pharmacopoeias and other product characteristics. In Thyme, the Genus Thymus; Stahl-Biskup, E., Sáez, F., Eds.; Taylor \& Francis: London, UK, 2002; ISBN 0415284880.

15. Lawrence, B.M.; Tucker, A.O. The genus Thymus as a source of commercial products. In Thyme, the Genus Thymus; Stahl-Biskup, E., Sáez, F., Eds.; Taylor \& Francis: London, UK, 2002; ISBN 0415284880.

16. Carović-Stanko, K.; Petek, M.; Grdiša, M.; Pintar, J.; Bedeković, D.; Ćustić, M.H.; Satovic, Z. Medicinal plants of the family Lamiaceae as functional foods-A review. Czech J. Food Sci. 2016, 34, 377-390. [CrossRef]

17. Brewer, M.S. Natural Antioxidants: Sources, Compounds, Mechanisms of Action, and Potential Applications. Compr. Rev. Food Sci. Food Saf. 2011, 10, 221-247. [CrossRef]

18. Fernandes, Â.S.F.; Barros, L.; Carvalho, A.M.; Ferreira, I.C.F.R. Lipophilic and hydrophilic antioxidants, lipid peroxidation inhibition and radical scavenging activity of two Lamiaceae food plants. Eur. J. Lipid Sci. Technol. 2010, 112, 1115-1121. [CrossRef]

19. Kindl, M.; Blažeković, B.; Bucar, F.; Vladimir-Knežević, S. Antioxidant and anticholinesterase potential of six thymus species. Evid.-Based Complement. Altern. Med. 2015, 2015. [CrossRef] [PubMed]

20. Szostak-Wegierek, D.; Kllosiewicz-Latoszek, L.; Szostak, W.B.; Cybulska, B. The role of dietary fats for preventing cardiovascular disease. Rocz. Panstw. Zakl. Hig. 2014, 64, 2013-2014.

21. FAO Fats and fatty acids in human nutrition: Report of an expert consultation. In FAO Food and Nutrition Paper; Food and Agriculture Organization of the United Nations: Rome, Italy, 2010; Volume 91, ISBN 9789251067338.

22. Martin, C.A.; De Almeida, V.V.; Ruiz, M.R.; Visentainer, J.E.L.; Matshushita, M.; De Souza, N.E.; Visentainer, J.V. Ácidos graxos poliinsaturados ômega-3 e ômega-6: Importância e ocorrência em alimentos. Rev. Nutr. 2006, 19, 761-770. [CrossRef]

23. Simopoulos, A.P. The importance of the ratio of omega-6/omega-3 essential fatty acids. Biomed. Pharmacother. 2002, 56, 365-379. [CrossRef]

24. Afonso, A.F.; Pereira, O.R.; Neto, R.T.; Silva, A.M.S.; Cardoso, S.M. Health-promoting effects of Thymus herba-barona, Thymus pseudolanuginosus, and Thymus caespititius decoctions. Int. J. Mol. Sci. 2017, 18. [CrossRef] [PubMed]

25. Miron, T.L.; Plaza, M.; Bahrim, G.; Ibáñez, E.; Herrero, M. Chemical composition of bioactive pressurized extracts of Romanian aromatic plants. J. Chromatogr. A 2011, 1218, 4918-4927. [CrossRef] [PubMed]

26. Pereira, O.R.; Peres, A.M.; Silva, A.M.S.; Domingues, M.R.M.; Cardoso, S.M. Simultaneous characterization and quantification of phenolic compounds in Thymus $\times$ citriodorus using a validated HPLC-UV and ESI-MS combined method. Food Res. Int. 2013, 54, 1773-1780. [CrossRef]

27. Sevindik, H.G.; Ozgen, U.; Atila, A.; Er, H.O.; Kazaz, C.; Duman, H. Phtytochemical studies and quantitative HPLC analysis of rosmarinic acid and luteolin 5-O- $\beta$-D-glucopyranoside on Thymus praecox subsp. grossheimii var. grossheimii. Chem. Pharm. Bull. 2015, 63, 720-725. [CrossRef] [PubMed]

28. Ložiene, K.; Venskutonis, P.R.; Šipailiene, A.; Labokas, J. Radical scavenging and antibacterial properties of the extracts from different Thymus pulegioides L. chemotypes. Food Chem. 2007, 103, 546-559. [CrossRef]

29. Baharfar, R.; Azimi, R.; Mohseni, M. Antioxidant and antibacterial activity of flavonoid-, polyphenol- and anthocyanin-rich extracts from Thymus kotschyanus boiss \& hohen aerial parts. J. Food Sci. Technol. 2015, 52, 6777-6783. [CrossRef] [PubMed]

30. Benbelaïd, F.; Khadir, A.; Abdoune, M.A.; Bendahou, M. Phytochemical screening and in vitro antimicrobial activity of Thymus lanceolatus Desf. from Algeria. Asian Pac. J. Trop. Dis. 2013, 3, 454-459. [CrossRef]

31. Mahboubi, A.; Kamalinejad, M.; Ayatollahi, A.M.; Babaeian, M. Total phenolic content and antibacterial activity of five plants of labiatae against four foodborne and some other bacteria. Iran. J. Pharm. Res. 2014, 13, 559-566. [PubMed]

32. Muhaisen, H.M.H.; Ab-Mous, M.M.; Ddeeb, F.A.; Rtemi, A.A.; Taba, O.M.; Parveen, M. Antimicrobial agents from selected medicinal plants in Libya. Chin. J. Integr. Med. 2016, 22, 177-184. [CrossRef] [PubMed]

33. Ertürk, Ö. Antibacterial and antifungal effects of alcoholic extracts of 41 medicinal plants growing in Turkey. Czech J. Food Sci. 2010, 28, 53-60. [CrossRef] 
34. Ferreira, F.M.; Dinis, L.T.; Azedo, P.; Galhano, C.I.C.; Simões, A.; Cardoso, S.M.; Domingues, M.R.M.; Pereira, O.R.; Palmeira, C.M.; Peixoto, F.P. Antioxidant capacity and toxicological evaluation of Pterospartum tridentatum flower extracts. CYTA J. Food 2012, 10, 92-102. [CrossRef]

35. Association of Official Analytical Chemists (AOAC). Official Methods of Analysis, 16th ed.; AOAC: Arlington, VA, USA, 1995.

36. Van Netten, C.; Hoption Cann, S.A.; Morley, D.R.; Van Netten, J.P. Elemental and radioactive analysis of commercially available seaweed. Sci. Total Environ. 2000, 255, 169-175. [CrossRef]

37. Pereira, O.R.; Silva, A.M.S.; Domingues, M.R.M.; Cardoso, S.M. Identification of phenolic constituents of Cytisus multiflorus. Food Chem. 2012, 131, 652-659. [CrossRef]

38. Pereira, O.R.; Macias, R.I.R.; Perez, M.J.; Marin, J.J.G.; Cardoso, S.M. Protective effects of phenolic constituents from Cytisus multiflorus, Lamium album L. and Thymus citriodorus on liver cells. J. Funct. Foods 2013, 5, 1170-1179. [CrossRef]

39. Catarino, M.D.; Silva, A.M.S.; Saraiva, S.C.; Sobral, A.J.F.N.; Cardoso, S.M. Characterization of phenolic constituents and evaluation of antioxidant properties of leaves and stems of Eriocephalus africanus. Arab. J. Chem. 2015. [CrossRef]

40. Ruiz, S.P.; Anjos, M.M. Dos; Carrara, V.S.; de Lima, J.N.; Cortez, D.A.G.; Nakamura, T.U.; Nakamura, C.V.; De Abreu Filho, B.A. Evaluation of the antibacterial activity of Piperaceae extracts and Nisin on Alicyclobacillus acidoterrestris. J. Food Sci. 2013, 78. [CrossRef] [PubMed]

(C) 2018 by the authors. Licensee MDPI, Basel, Switzerland. This article is an open access article distributed under the terms and conditions of the Creative Commons Attribution (CC BY) license (http://creativecommons.org/licenses/by/4.0/). 